\title{
A LITERATURA ORAL COMO FORÇA DE EXPRESSÃO DA CULTURA POPULAR: O GRITADOR
}

\author{
FRANK CARDOSO LUMMERTZ \\ Universidade do Estado de Santa Catarina
}

\section{RESUMO}

Contadores de história são comuns em todo o território nacional, e a variedade de lendas, contos, fábulas e anedotas é incalculável. Essas singulares manifestações culturais aparecem por todo o mundo. Africanos, asiáticos, europeus e americanos: as pessoas do mundo todo transmitem 0 seu conhecimento por meio da palavra falada através do tempo. Não raro, às vezes esses conhecimentos espalhados pelos continentes se encontram e se fundem, adquirindo uma variedade de riquezas culturais ímpares. São as músicas cantadas e encenadas junto à literatura falada que constituem, em síntese, o poder da palavra no universo cultural da humanidade. Duas facetas empregam o sentido da oralidade: uma assumida pela história e outra assumida pela literatura, ora fundindo-se, ora distinguindo-se. É explicitamente específica a figura do contador, do narrador popular, aquele que unicamente se recorda das histórias fantasiosas ou não, e, nesse momento, ganha importância a partir de uma construção sociocultural. É durante a sua experiência de vida que ele, o contador, ouviu ou vivenciou as histórias para recordá-las e contá-las em uma roda de bate-papo com familiares e amigos. São os casos e são as lendas, é o real e é o imaginário, fundindo-se dentro de uma perspectiva sociocultural. $O$ presente artigo busca intermediar significados encontrados em narrativas orais, presentes no imaginário e nas representações feitas pelo contador da história, e tenta observar elementos tidos como o real, capazes de transmitir história do tempo presente. Essa pesquisa se restringiu a vinte e dois moradores do entorno do Parque Nacional de Aparados da Serra, município de Praia Grande, Santa Catarina. Em sua integralidade destaca-se pela riqueza de detalhes históricos locais, regionais e até de aspecto nacional. Restringi o trabalho a um único exemplo adquirido nas entrevistas: a "Lenda do Gritador", um conto local ou "causo acontecido" - como diriam alguns dos moradores - das grotas dos Aparados da Serra. Por fim, registro a importância dessas lendas, histórias e causos acontecidos, capazes de produzir sentido para diferentes grupos sociais, que num tempo passado viviam longe das redes de energia elétrica, comunicação e estradas automotivas, nesta busca que "mistura" literatura oral com uma leitura de olhar historiográfico.

PalaVRAS-ChAVE: Cultura e identidade; História e literatura oral; Imaginário popular; Cotidiano.

\begin{abstract}
Storytellers are common throughout the country, and the variety of legends, tales, fables and anecdotes is incalculable. These unique cultural manifestations appear all over the world. Africans, Asians, Europeans and Americans: people from around the world pass on their knowledge through the spoken word in the course of time. Not rarely, sometimes this knowledge spread across the continents meets and merges, acquiring a variety of unique riches. These are the songs sung and performed by the spoken literature, in short, the power of the word in the cultural universe of humanity. Two facets employ the sense of oralness: one of them in the form of history, and the other in the form of literature, sometimes merging, sometimes moving apart. An explicitly specified figure is that of the contador, the popular narrator, who only remembers fanciful stories or not, who in that moment becomes important based on a cultural construction. It is during his life experience that he, the narrator, heard or experienced these stories to remember and recount them on to a group of family members and friends. Such are the cases and the legends, in which the real and the imaginary merge within a sociocultural perspective. This article seeks to mediate meanings found in oral narratives, sometimes present in the imagery and representations by the teller of the story, now trying to observe elements taken as real, capable of transmitting history of the present time. This research was restricted to twenty-two individuals who live in the surroundings of the National Park of Aparados da Serra, municipality of Praia Grande, Santa Catarina, whose accounts stand out for the wealth of historical detail with a local, regional and sometimes even national aspect. This work is restricted to one specific sample obtained in the interviews: the "Legend of the Screamer" ("O Gritador"), a local tale or "causo acontecido" (an experienced event), as would say the locals who inhabit the mountainside of Aparados da Serra. Finally, I make a remark on the importance of these legends, stories and 'experienced tales', as they are capable of producing meaning for different social groups, which in the past lived far from power grids, communications and automotive roads, in this search in order to "blend" oral literature with historiographical look.
\end{abstract}

KEYWORDS: Culture and identity; History and oral literature; Popular imaginary; Daily culture. 


\section{Apresentação}

Na história humana, nem sempre o comum foi ser possuidor da energia elétrica, nem as estradas eram de fácil acesso, com pontes e pavimentação. É só com o advento tecnológico no fim do século XIX e início do século XX que as sociedades adquirem essa roupagem iluminada e repleta de caminhos interligados.

Para imaginar como era a vida antes do advento tecnológico, quando os lares não tinham energia elétrica e a vida era sem o domínio automotivo pelas estradas, o cidadão contemporâneo poderá visitar aldeias indígenas ou comunidades tradicionais espalhadas pelo interior do Brasil. No entanto, o tempo histórico dos grandes acontecimentos não é homogêneo, e tempos históricos coexistem. Nem todas as pessoas ou comunidades adotaram essas transformações num dado momento.

Hoje, com as possibilidades da historiografia, nem precisamos nos deslocar muito do local em que habitamos para ainda encontrarmos vestígios desse tempo pré-eletricidade, pré-automóvel, nem que seja aquele vestígio encontrado no passado histórico ou na memória das pessoas mais antigas, que viveram uma experiência anterior ao advento da eletricidade.

Foi com essa visão temporal que este artigo se constituiu. A sua pesquisa foi realizada com moradores do entorno do Parque Nacional de Aparados da Serra, no interior do Estado de Santa Catarina. Esses moradores, ainda hoje, guardam lembranças de uma vida onde a luz gerada era pelo lampião e as estradas eram somente trilhas, picadas, abertas por entre a mata. Por meio da metodologia da história oral, foi captada uma série de narrativas a respeito de três temas principais: a ecologia, a cultura e a comunidade.

Dos entrevistados, quando indagados sobre cultura, era comum ouvir uma série de histórias tidas como reais, que nos levam de volta a um passado recheado de presenças fantasiosas e sobrenaturais. Desse modo, o presente trabalho estabeleceu um estudo relacionado à memória e suas representações, ${ }^{1}$ sejam do real histórico, seja do imaginário, o que podemos aqui chamar, como construção narrativa, de uma Literatura Oral.

Devido à vasta gama de informações, o trabalho foi restringido a um único exemplo adquirido nas entrevistas: a "Lenda do Gritador", um conto local ou "causo acontecido", ${ }^{2}$ como diriam alguns dos moradores das grotas dos Aparados da Serra.

\footnotetext{
1 No presente trabalho as representações são de cunho social, que nos direcionam para elementos tidos como culturais.

2 Como "causo", entenderemos aqui uma expressão literária de cunho oral nas formas de anedotas, contos, crônicas, lendas e poesias.
} 


\section{"Causo acontecido"}

Para buscar entender a riqueza cultural que os moradores das encostas da Serra Geral na região dos Aparados da Serra vieram adquirindo ao longo do século XX, foi organizada uma coletânea de literatura oral sobre os referidos "causos acontecidos". ${ }^{3}$

Conforme cada narrativa colhida, os "causos acontecidos" assumem características de lendas, de anedotas, poesias e contos. Também é pertinente observar que essa pesquisa se restringiu a vinte e dois moradores do entorno do Parque Nacional de Aparados da Serra no município de Praia Grande (SC); que a sua integralidade se destaca pela riqueza de detalhes históricos, seja local, regional e até de aspecto nacional; e que esses detalhes da vida cotidiana, contidos nos "causos", conferem à "linguagem e, de modo mais geral, às representações, uma eficácia propriamente simbólica de construção da realidade" ${ }^{\prime 4}$.

Obviamente, essa coletânea de transcrição, transmitida pela oralidade dos entrevistados, com todo seu enredo literário, já teve seus dias mais populares quando, nos anos 1950 e antes dessa data, ${ }^{5}$ era costume contar e recontar essas histórias faladas, em volta da fogueira ou enquanto se cozinhava o alimento no fogão a lenha. Constituía uma ação de assistir os mais velhos educarem os novos através dessas falações populares, quase que como parábolas. Pouco mais tarde, já na década de 1960, quando o popular foi atingido pelas ondas do rádio, começaram a surtir efeito as histórias de caipiras aventureiros, como o Mazzaropi, ou o medieval adaptado ao jeitinho brasileiro de Pedro Malasartes, que juntos inundaram o imaginário da cultura popular por esses tempos.

A partir de então, levanto a primeira questão para se pensar História a partir dessa literatura oral. Como os moradores dessas comunidades desprovidas de energia elétrica e com baixo nível de escolaridade adquiriam a cultura ou sapiência desses "causos"?

3 Essa coletânea está disponível na monografia de LUMMERTZ, F. C.. Cânions e História: Comunidade Tradicional, Cultura Popular e Ecologia nos Aparados da Serra. TCC apresentado ao Curso de História, Habilitação em Bacharelado, do Centro de Ciências Humanas e Educação FAED/UDESC. Florianópolis, 2009. Disponível em: http://www.pergamumweb.udesc.br/dadosbu/000000/00000000000C/00000C1B.pdf.

${ }^{4}$ BOURDIEU, P. Linguagem e poder simbólico. In: Economia das trocas lingüísticas. O que falar quer dizer. São Paulo: Edusp, 1996, p. 108.

${ }^{5}$ Para a problemática desta pesquisa, é difícil estabelecer uma data em que as pessoas e seus grupos familiares deixaram de praticar tais histórias e "causos" no seu cotidiano. O que proponho para essa pesquisa é que com a chegada das rádios e a popularização desses aparelhos domésticos, as comunidades rurais de interior começaram a compartilhar informações distantes de sua realidade material. Neste caso, é a partir dos anos 1950 que a energia chegou na região; portanto, é quando o rádio adquire uma importância mais significativa nos lares. Tento estabelecer aqui as "condições de emergência" que geravam a criação e manutenção dessa recreação cultural: o contar histórias. 
Para tanto, aponto alguns marcos para o estudo em questão:

Primeiro, a objetividade de réplica: alguém em algum lugar ouviu falar de tal história. Essa réplica teria como origem algum livro lido por alguém e contado a muitos, ou por meio da difusão de histórias ligadas ao rádio; em segundo lugar, podemos somar a esse fato a questão da experiência. Alguém em algum lugar viveu, presenciou tal motivo, fato, evento que inspirou, proporcionou tal constituição do enredo que passaria a ser replicado às demais pessoas. Geralmente, os dados obtidos nas vinte e duas entrevistas apontaram para histórias típicas da região e de cunhos originais, o que demonstra muitos aspectos do cotidiano do passado dessas pessoas; e, por último, a figura do narrador. Quem contava essas histórias, quando, e para quem se contava? E elas tinham alguma finalidade? Pois como lembra Benjamin: "para todo narrador há a necessidade de ter bons ouvintes" ${ }^{\prime \prime}$.

Claro que o costume de contar histórias é comum a todas as organizações sociais, sejam organizações tradicionais ou não, espalhadas pelo planeta Terra. No Brasil, sabe-se que índios de diferentes tribos, de Norte a Sul, contavam suas aventuras durante a Paranduba. A tradição oral indígena guardava não somente o registro dos feitos ilustres da tribo, para emulação dos jovens, uma espécie de material cívico para o entusiasmo, "como também as estórias facetas, lendas, fábulas, contos e o ritmo das danças inconfundíveis. O Pajé sacerdote reservaria, como direito sagrado, a ciência medicamentosa, os ritos e a confusa teogonia"7. Os guerreiros que envelheciam possuiriam o arquivo das versões orais. Essa continuidade da memória falada era tão normal e poderosa que compreendemos como foram transmitidas, documentadas e retransmitidas pelos naturalistas, exploradores e missionários dos séculos passados.

Um exemplo dessa nuance da história oral vem de uma herança negra, tão rica e variada que, graças a sua resistência, camuflou-se e sobreviveu até os nossos dias. Por toda a África, ainda se mantêm seus "escritores" verbais, oradores das crônicas antigas, contadores das glórias guerreiras e sociais, antigas e modernas, proclamadores das genealogias ilustres. São os akpalô, kpatita, ologbo, griotes. Constituem castas, regras, direitos, deveres, privilégios. De geração em geração, mudando de lábios, persiste a voz evocadora, ressuscitando o que não deve morrer no esquecimento.

Por outro lado, também de extrema significância, o português emigrava da Europa com o seu mundo na memória:

Trazia o Lobisomem, a Moura encantada, a Maria sabida, Doce na morte, as andanças do Pedro Malasarte fura vida, Bruxas, Fadas, Assombrações, Monstros, Moleque de carapuça vermelha,

6 BENJAMIN, Walter. Magia e técnica, arte e política. Obras escolhidas. São Paulo: Ed. Brasiliense, 1994, p. 198.

${ }^{7}$ CASCUDO, Luíz da Camara. Literatura oral no Brasil. Itatiaia: São Paulo: Ed. da Universidade de São Paulo, 1984, p. 80; 152; 170. 
Gigantes, Príncipes, Castelos, Tesouro enterrado, Sonho de aviso, Oração-forte, Medo do escuro, etc. ${ }^{8}$

\section{O narrador}

A experiência que passa de pessoa para pessoa é a fonte a que recorrem todos os narradores. $\mathrm{E}$, entre as narrativas escritas, as melhores são as que menos se distinguem das histórias orais contadas pelos inúmeros narradores anônimos. Entre eles, existem dois grupos, que se interpenetram de múltiplas maneiras. A figura do narrador só se torna plenamente tangível se temos presentes esses dois grupos. "Quem viaja tem muito para contar", diz o povo, e com isso imagina o narrador como alguém que vem de longe. Mas também escutamos com prazer o homem que ganhou honestamente sua vida sem sair de seu país e que conheceu suas histórias e tradições ${ }^{9}$.

Contadores de história são comuns em todo o território nacional. A variedade de lendas, contos, fábulas e anedotas é incalculável. Essas verdadeiras manifestações culturais aparecem por todo o mundo. Africanos, asiáticos, europeus e americanos - as pessoas transmitem o seu conhecimento por meio da palavra falada através do tempo.

Não raro, às vezes, esse conhecimento espalhado pelos continentes se encontrava e se fundia, adquirindo uma variedade de riquezas ímpares e singulares. São as músicas cantadas e encenadas junto à literatura falada que constituem, em síntese, o poder da palavra no universo cultural da humanidade. Dessa forma, duas facetas empregam o sentido da oralidade: uma assumida pela História e outra assumida pela Literatura, ora fundindo-se, ora distinguindo-se.

É a figura do contador, do narrador popular, aquele que unicamente se recorda das histórias, fantasiosas ou não, que nesse instante ganha importância a partir de uma construção cultural, estritamente correlacionado com o meio social ao qual está inserido.

É durante a sua experiência de vida que ele, o contador, ouviu ou vivenciou essas histórias para recordá-las e contá-las em uma roda de bate-papo com familiares e amigos. São os casos e são as lendas, é o real e é o imaginário se fundindo dentro de uma perspectiva sociocultural.

\footnotetext{
${ }^{8}$ Ibidem, p. 80; 152; 170.

${ }^{9}$ BENJAMIN, op. cit, p. 198.
} 
Este trabalho buscou intermediar significados encontrados em narrativas orais, presentes no imaginário e nas representações feitas pelo contador da história, e buscou observar elementos do tido como real, capazes de transmitir a história do tempo presente. Para isso, utilizou-se a "réplica" de um "causo acontecido" muito ouvido na região dos Aparados da Serra que é o causo do "Gritador", uma lenda que a partir de sua popularidade inundou a imaginação de muitas pessoas daquela região. A questão que elaborei trata do seguinte problema: é possível encontrar elementos da História em lendas, em contos, tidos como fantasiosos?

\section{O Gritador}

As histórias faladas de tempo em tempo são comuns, e a figura do narrador, ainda mais. Não é nenhuma novidade encontrar esse dois elementos em uma comunidade rural no interior do Brasil.

Para tanto, o tema desta pesquisa é fazer uso de um caso específico: a lenda do Gritador, e analisar historicamente traços do passado daquela região, contextualizar um determinado período por meio de uma lenda cultural e literária, neste caso oral. Em seguida, o artigo também buscará interpretar o "imaginário" encontrado nessa mesma lenda.

Este trabalho aponta para duas versões da lenda do gritador; uma, conferida por mim a partir das muitas versões que escutei desde criança, e que ao longo do tempo vim construindo em forma literária. É importante conhecer essa versão para, em seguida, conhecer a segunda versão, que é o "causo acontecido" de um dos entrevistados desta pesquisa. Vejamos a seguir a primeira delas:

Os mais antigos moradores do entorno do parque, nos grotões e coxilhas serranas, contam que em uma das noites estreladas nos Aparados da Serra em um tempo já passado, houve um antigo morador cujo nome não é revelado, porque recebeu uma maldição. Uns dizem que é alma penada, outros afirmam já tê-lo visto por aí. O caso foi que, quando vivo, após um dia de muito trabalho campeiro pelas coxilhas de cima da serra, o tal fulano foi convidado para uma fandangueira aos redores do pé da serra. Como de costume, amarrou seu velho cavalo Malacara e foi tomar um banho para se limpar do suor. Demorou tanto debaixo da água que a sua mãe, ao perceber que o cavalo estava exausto de cansado, decidiu solta-lo, pois assim o cavalo velho de guerra poderia descansar em paz. Tal fulano, ao sair do molho e ao perceber a burrada que sua mãe acabara de cometer, ficou muito enfurecido e descontrolou-se. Chamou tudo que foi de nome feio, rogou umas trezentas malesas, foi praga pra todos os lados, pois sabia que chegaria atrasado ao baile. Finalmente, como numa tentativa de evitar o atraso, pegou as 
selas e rédeas de seu cavalo e acabou por encilhar a velha, sua própria mãe. Tadinha daquela velha senhora! (...) Foi aí que aconteceu o inevitável. A pobrezinha, tão cansada de tanto esforço inútil aos galopes com seu filho às costas, acabou por falecer. Mas antes, um pouco antes de morrer, ela rogou uma praga ao filho: "Minha alma ao morrer subirá diretamente ao céu enquanto que a sua, filho desonrado, nunca mais terá descanso". Foi que ao voltar para casa em uma serração de tirar as vistas, o tal do fulano acabou se perdendo entre campos, coxilhas e capões de araucária em meio à brancura da viração. Dito e feito: sua alma amaldiçoada nunca conseguiu descansar e dizem que ela anda solitária, atordoada, dando gritos de dor pelas grotas, campos e cânions dos Aparados da Serra. Também os mais velhos dizem que se algum sujeito resolver responder aos berros de agonia, essa alma penada vem e pega o infeliz. E é assim que, ainda hoje, os aventureiros, os caçadores, agricultores, os fazendeiros ainda escutam os berros atordoados do Gritador. ${ }^{10}$

Observemos agora a versão contada pelo Senhor Valdomiro:

Eu sei história. Uma vez até, eu vinha do moinho, e esse moinho era atrás desses morros, só que era longe só; gastava um dia inteirinho para ir no moinho moer farinha, atafona como se diz. Eu anoiteci na estrada, bem de trás deste morro, trilha de cargueiro só; certo ponto da estrada, tava até chovendo e já era umas 9 horas da noite, pouca demora o tal de gritador gritou, não sei se você já ouviu falar? Mas gritou num grotão que tem ali embaixo, e eu no Faxinal, aquilo vinha de grota acima, dereito a onde eu estava, mas era rápido! Esse grito você não sabe se é um cachorro acuando, um touro urrando se é um animal orniando, é tudo junto e não dá para diferenciar o que é, mas é horrível ! É horrível mesmo! (...).

Depois no fim de tudo eu vou te contar a história. (...) Como daqui lá no rio, ele deu outro grito, era uma tropeada como a de uma tropa de gado, aquele tropeirão direito ao meu lado. E quando chegou aonde eu estava, o meu cavalo, que era bem bom, bem gordo, bem reforçado mesmo, quando ele montou na garupa do cavalo, o cavalo caiu, o cavalo caiu mas antes de ele montar na garupa eu senti um vento nas minhas costas, quando ele montou na garupa o cavalo caiu, daí eu levei a mão assim e disse:

${ }^{10}$ Essa versão encontra-se na monografia de LUMMERZ, F. C.. op. cit., p. 91. 
"- Bênça! Só pode ser um diabo que está ai?"

Eu não tinha medo de nada. Daí quando eu disse assim, ele saiu, saiu e o cavalo se alevantou comigo em cima e ele já gritou como daqui lá no salão! E se foi!

"- Mas isso aí aconteceu comigo mesmo!" (...).

Isso ai que eu posso explicar, essa história, os meus antigos, meu pai, minha mãe diziam que isso foi um filho que uma vez foi num baile e chegou do baile e amarrou o cavalo e foi dormir. Daí a mãe dele ficou com dó do cavalo rinchando de fome, foi lá e soltou o cavalo dele para pastar, ele acordou e queria pegar o cavalo para ir em outras farras dele, ficou sabendo que tinha soltado e ele pegou a mãe dele, encilhou, montou e esporou muito ela, daí ela rogou uma praga nele, que ele ia ficar velho gritando pelo mundo sem ter salvação nenhuma, então foi da vez que ele se tornou esse tal de Gritador que the falei que anda pelo mundo tudo (...).

Meus bisavós, meus avós que contaram pro meu pai, minha mãe e eles passaram pra nós. Esse que eu tava contando foi comigo mesmo. Porque ele existe, ele é pelo mundo todo, se ele não ta num lugar, ele ta noutro. ${ }^{11}$

Através dessa tradição oral, sabe-se que essa lenda do Gritador existe em múltiplas variáveis e se desloca tanto nas encostas da Serra Geral como no planalto serrano gaúcho. Suas variantes são encontradas em cidades como Praia Grande, Jacinto Machado, Cambará do Sul, São Francisco de Paula, São José dos Ausentes e provavelmente em muitos outros municípios do entorno dos Aparados. Sua origem é desconhecida, não se sabe o tempo em que ela surgiu. É provável que gerações anteriores à de Seu Valdomiro, acima registrada transcrita - já mencionassem a existência do Gritador.

Provavelmente já faz, pelo menos, um meio século de existência. Luís da Câmara Cascudo, em duas ocasiões passadas, mencionou em obra a existência de um possível "Gritador" no folclore brasileiro. No primeiro momento, encontrado no Dicionário do Folclore Brasileiro, descreveu um "Gritador duende do Vale do São Francisco, conhecido como Zé Capiongo que vive gritando dentro da noite, dizem ser alma penada de um vaqueiro" ${ }^{\prime 12}$. Já em sua obra intitulada Geografia dos Mitos Brasileiros, o autor descreveu a existência de um Bradador, mito regional de São Paulo, Minas Gerais, Paraná e Santa Catarina.

Obviamente, as lendas correm o mundo, mas declarar que a lenda do Gritador dos Aparados da Serra é de influência da lenda do Rio São Francisco é quase que equivocado. Ao menos, de acordo com nossos importantíssimos narradores, elas se parecem bem originais e oriundas dessa região Sul brasileira.

\footnotetext{
${ }^{11}$ Seu Valdomiro de Oliveira, 68 anos, entrevista concedida no dia 03 de setembro de 2008. Localidade de São Roque, Praia Grande, SC.

${ }^{12}$ CASCUDO, Luíz Camara. Dicionário do folclore brasileiro. 10a edição. São Paulo: Global, 2001, p. 266.
} 
Portanto, consideramos como típicas as versões contadas pelos entrevistados, oriundas da região dos Aparados da Serra.

Provavelmente, muitas lendas se assemelharam a essas que foram contadas, já que o tema principal são gritos na noite. Vale enfatizar o fato de pessoas comuns, moradores rurais, acreditarem realmente na existência do tal Gritador, uma alma penada, tendo muitas dessas histórias destacadas como "causo acontecido" - como fato que aconteceu com eles, uma experiência de contato com o sobrenatural, registrada na memória e passada oralmente.

Além da importância cultural aqui já destacada, ou seja, pelo fato de hoje esses "causos" serem vistos como pertencentes ao folclore regional, o objetivo deste trabalho é extrair elementos de historicidade para contextualizar a vida social desses antigos moradores da região - em um tempo em que as redes de energia elétrica não existiam, e um lugar onde as estradas eram mais semelhantes a trilhas e picadas por entre as matas.

\section{Elementos para uma história: Territórios e sujeitos}

É possível, pois, encontrar elementos da História em lendas e contos tidos como fantasiosos?

Antes de qualquer coisa, só a importância do assim-chamado "causo acontecido" já revela a significância da pesquisa. Uma vez que essas histórias ainda permeiam a memórias das gerações, podemos ver essa relação tanto simbólica como histórica, como também um objeto subjetivo da história social dessas pessoas.

Por outro lado, partindo da ideia de que esses "causos acontecidos" emergiram do que foi tido como "real" e "verdadeiro", possuímos outro material para o fazer da história. Segundo Pierre Bourdieu, a linguagem, além de comunicar, é possuidora de uma "eficácia simbólica" que garante a produção dos emissores e receptores legítimos. Para ele:

A eficácia simbólica das palavras se exerce apenas na medida em que a pessoa alvo reconhece quem a exerce como podendo exercê-la de direito, ou então, o que dá no mesmo, quando se esquece de si mesma ou se ignora, sujeitando-se a tal eficácia, como se estivesse contribuindo para fundá-la por conta do reconhecimento que lhe concede. ${ }^{13}$

Cabe ressaltar que Bourdieu salienta o sentido de uma linguagem religiosa instituída e professada pelo sacerdócio. No entanto, neste caso apresentado, se pensarmos a respeito de quem é o narrador de tal "causo", acreditamos, por ora,

${ }^{13}$ BOURDIEU, op. cit., p. 95. 
que é aquele que viveu tal acontecimento, que teve experiência. Ou seja, já advêm dele próprio o "poder instituído"14 de contar tal causo, porque foi ele quem supostamente viveu tal experiência. Mas podemos nos perguntar: e quando não foi o sujeito que conta que presenciou tal acontecimento? Ora, geralmente essas histórias eram contadas pelos mais velhos, como nos lembra 0 senhor Valdomiro. Portanto, um pai, um avô, um tio é reconhecidamente dono da palavra e já tem em sua história de vida o "rito instituído" para ser o possuidor de tal narrativa; o narrador.

A força da representação está inserida em praticamente boa parte dos atos humanos, e nela se reconhece o valor material e o valor simbólico por ela anunciados. Neste caso, podemos pensar: além do cunho de entretenimento das contações de histórias, qual motivo um pai, um avô ou uma pessoa que viveu tal causo pode ter para transmiti-lo?

Além da referência ao ocorrido, histórias de assombrações nos remetem ao medo, ao perigo. Numa região desprovida de caminhos e luzes de redes elétricas, essas histórias poderiam tencionar para certa educação aos filhos e pessoas próximas, como numa moral, espécie de, e para, impor "limites" aos mais jovens, proposto por tal grupo de adultos, ou seja: onde se pode ir, com quem se pode ir, como se pode ir? E os cuidados necessários para que tal experiência sobrenatural não se repita, e, caso se repita, os cuidados para afastá-la: "eu levei a mão assim e disse: - Bênça! Só pode ser um diabo que está aí?"15

Simultaneamente a esse valor simbólico que inclui no "real" uma representação do imaginário sobrenatural, partimos para uma análise mais detalhada das palavras do senhor Valdomiro, contidas no "causo acontecido do Gritador".

Num primeiro momento, ele descreve onde tal experiência ocorreu: "- Eu vinha do moinho, e esse moinho era atrás desses morros, só que era longe só, gastava um dia inteirinho para ir no moinho moer farinha, atafona como se diz". Aqui, não temos a visão óptica do morro, mas podemos imaginar a distância percorrida para se poder moer farinha, "um dia" montado no lombo do cavalo. Uma representação de tempo, comum à época em questão.

E para aqueles que hoje visitam a localização exatamente onde Valdomiro descreve tal acontecimento, o viajante não vai encontrar moinho algum lá. Isso nos indica, no relato do "causo" acontecido, a existência física de um moinho nessa localidade e consequentemente as relações socioeconômicas promovidas por essa atividade. Seguindo a história, Valdomiro esclarece que "- Aquilo vinha de grota acima". Ou seja, o som que se escutava vinha de uma grota. Para esses moradores locais, grota significa um vale abrupto por onde desce um rio, que geralmente é de difícil acesso e onde não há moradores residindo. Cria-se, então, a partir do sentido das palavras do senhor Valdomiro, uma noção de território. $O$ território habitado, utilizado pelos moradores para fazer suas

${ }^{14}$ Ibidem, p. 100.

${ }^{15}$ Trecho da lenda do Gritador segundo Valdomiro de Oliveira, 2008. 


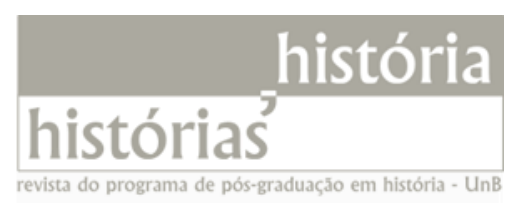

habitações, roças, engenhos e moinhos; e o território não habitado, do desconhecido. Tem-se aqui a noção de territoriedades e de limites; são as fronteiras imaginadas, assim como as grotas, que também eram utilizadas como divisas entre propriedades.

Outro detalhe que se percebe é que muitas vezes, os caminhos, as poucas estradas passavam próximas a lugares desconhecidos, dando margem para a "aparença do sobrenatural", como por exemplo, uma estrada que passa ao lado de um cemitério e que acabava inundando as mentes das mais apavorantes histórias de assombrações. Certo que em outras entrevistas coletadas, ${ }^{16}$ quando o assunto era o sobrenatural, muito se fazia menção a lugares, a territórios demarcados, como cemitérios e locais onde essas assombrações foram vistas.

Outros elementos para se fazer história que estão contidos nessas lendas são os objetos e sujeitos de época. Só nas palavras de seu Valdomiro podemos encontrar objetos tais como: cargueiro, atafona e sujeitos como tropa de gado e seu cavaleiro condutor. Partindo do tempo presente, dificilmente o viajante que chegar na comunidade de São Roque encontrará uma atafona, cargueirinhos e muito menos tropas de gado. Historicamente, ${ }_{1}^{17}$ sabe-se que nessa região até os anos 1980 era comum encontrar esses objetos e sujeitos mencionados. Com o surgimento de moinhos mecanizados, estradas de rodagem automotivas e camionetas, as atafonas, que eram um espaço socioeconômico, os cargueirinhos, que eram meios de transporte puxados por mulas, e as tropas de gado foram perdendo seu espaço e diminuindo como prática econômica.

\section{Imaginário e representação: o meio social}

Como os moradores dessas comunidades desprovidas de energia elétrica e com baixo nível de escolaridade adquiriam esses "causos"?

Nessa época, era bem comum a não alfabetização das pessoas. A primeira escola na região foi inaugurada na década de 1930 em frente à praça São Sebastião, no atual centro da cidade de Praia Grande (SC). ${ }^{18}$ Sabe-se que a precariedade das estradas e a dificuldade do transporte atrapalhavam os alunos do interior, como os da comunidade de São Roque, para chegarem à escola. Mesmo assim, era possível que muitos estudantes frequentassem as escolas e lá

\footnotetext{
${ }^{16}$ Para este artigo, detive-me exclusivamente na entrevista concedida pelo Senhor Valdomiro.

17 BRIGHTWELL, NODARI e KLUJ abordam a colonização dessa região a partir do trânsito de mercadorias entre as estâncias dos campos de cima da serra com as roças da planície litorânea. (Cf. BRIGHTWELL, Maria das Graças S. L.; NODARI, E. S.; KLUJ, João. Saberes e sabores de Praia Grande: Práticas alimentares, memória e história. Universidade Federal de Santa Catarina Pró-Reitoria de Cultura e Extensão, 2005).

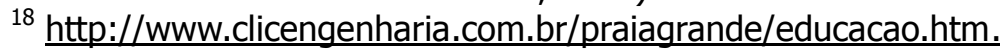


ficassem sabendo de outras histórias oriundas dos livros, e, um pouco mais tarde, das histórias transmitidas via rádio.

Para tanto, como mencionaram os entrevistados, a maioria das histórias surgia de alguma "experiência", seja com o próprio narrador da história, seja por outro alguém que a transmitiu a terceiros, que passaram então a narrar tal história. Para esse fato, atestamos a presença do mítico, do sobrenatural na vida das pessoas, do tido como "realidade", o imaginário que determinados grupos faziam de elementos naturais, cuja explicação fugia do "racional". Como por exemplo, explicar um grito agonizante em meio à mata em plena noite? Como explicar que um cavalo forte, gordo arriou sem nenhum peso adicional na garupa?

No próprio folclore brasileiro, temos uma explicação para isso, a Mboi-tatá - a "cobra de fogo". Até meados no século XX, nas regiões de interior do país, justamente nas localidades onde não existiam energia elétrica e redes públicas de iluminação, era comum as pessoas avistarem a "Mboi-tatá" com frequência. Ou seja, uma presença do meio natural, imaginada como sobrenatural e representada como uma "cobra de fogo", que alcançou tamanha popularidade que virou folclore. Mais tarde, a ciência apareceu com a explicação de que essa cobra é um fogo fátuo.

Pela Geografia dos Mitos Brasileiros de Câmara Cascudo, Santa Catarina aparece como o Estado brasileiro onde mais sobrevive o popular lendário da Cobra-de-Fogo, a Mboi-tatá. Ora considerada como guardiã de ouros e tesouros enterrados, ora como a serpente guardiã dos campos. Para a ciência, o fenômeno é conhecido como fogo-fátuo, desprendido de lugares pantanosos onde se encontram animais em decomposição ou nos campos de folhagem apodrecidas. Ou seja, o metano que se desprende de algo orgânico em decomposição. Tamanha é a fama do folclore que jamais essa explicação científica interferirá na propagação da Mboi-tatá pelo Brasil nas próximas gerações.

Como historiadores, extraímos desses "causos" a essência do meio social, ou seja, a dinâmica daquilo que era dialogado entre as pessoas além de assuntos econômicos, políticos e do trabalho, mas assuntos corriqueiros, cotidianos que determinados grupos, com singulares histórias, mantinham, dando representação aos objetos e sujeitos, aos seres - naturais ou sobrenaturais - do lugar no qual estão inseridos. Muitas dessas lendas, em histórias tidas como fantasiosas e ficcionais, ilustram aspectos das relações sociais e culturais que grupos rurais mantiveram durante gerações. São as "consciências de experiências", suas crenças e práticas enraizadas nessas recreações de contar "causos", de significar o presente, de ilustrar aspectos cotidianos, através da fala, pelo falado.

Não vamos ouvir lendas de boto no Sertão, por exemplo, pois o aspecto geral que essa lenda demanda é de rios e mares, de populações próximas a esse meio ambiente, de ribeirinhos. São essas relações entre o real, concreto e 0 imaginado que nos instigam como pesquisadores dos homens no tempo, a fazer uma história cultural, uma história das mentalidades, do cotidiano. 
De modo geral, em uma análise simples, mas abrangente, a característica da economia rural até meados do século XX era a sua relação com a situação ambiental, a disponibilidade do solo, das chuvas, das estações, e com a dificuldade de transportes, que de certa forma limitavam ou possibilitavam os trâmites dos negócios. No caso aqui exemplificado, entendemos que esse lugar é uma região de relevo caracterizado por morros e montanhas que ligam e dão acesso ao planalto serrano, em que se formaram muitos grotões que beiram a planície do litoral, onde foi possível praticar uma agricultura rústica tradicional, de cunho familiar, mantendo um contato com a pecuária dos campos de cima da serra.

Dessa forma, a partir da geografia do lugar, entende-se um pouco do meio social no qual esse grupo estava inserido. Nesse caso, o contexto foi exemplificado através do relato de um morador. Porém, em um sentido metodológico, é importante coletar informações de diferentes atores sociais do período histórico em questão como fontes e relacioná-las a uma problemática histórica, ou seja: moradores de uma comunidade rural onde a energia elétrica era restrita e onde havia poucas estradas. Portanto, para a História, os causos eram comuns, faziam parte do diálogo corriqueiro do dia-a-dia, em que 0 transporte dessas mercadorias, na prática, eram feito necessariamente com a ajuda de animais. Todos esses dados e fatos estão contidos no relato do narrador do causo. Se isso é verdade, é com esse processo metodológico que surge a possibilidade de montar uma narrativa histórica retirando das lendas, dos "causos acontecidos" aspectos de uma micro-história cultural e do seu meio social.

\section{Considerações finais}

O mundo da fantasia projeta o homem para dentro das regiões culturais inimagináveis do fantástico sobrenatural. É um mundo onde o pensamento humano tem poderes quase ilimitados para viver a beleza de sonhos invisíveis e para elevar-nos aos píncaros de mundos superiores a este em que nascemos, vivemos e morremos $^{19}$.

Cada região do país reconhece aspectos de suas manifestações culturais, sejam elas na música, na dança, na coreografia, na estética, nos personagens mencionados, nas lendas, mitos, no folclore e na própria história do lugar. A exemplo, faço uso das atribuições feitas à ilha de Santa Catarina, antiga

${ }^{19}$ CASCAIS, Franklin. O fantástico na I/ha de Santa Catarina. Florianópolis: Ed. UFSC, 2003, p. 25. 
Desterro, que no imaginário popular tem a presença marcante das bruxas, feiticeiras e animais fantásticos, assim como demonstrou o folclorista e escritor Franklin Cascais em suas pesquisas e publicações.

Não só a ilha de Santa Catarina, mas toda a Amazônia brasileira é coroada de mitos e lendas que demonstram a presença do fantástico. São botos se transformado em homens, índias em flores, e os curupiras; ou os Maty Taperê, que são verdadeiros guardiões das florestas a assustar os maus intencionados. Todas essas manifestações são histórias que tentam explicar o "fantástico", as "aparições", o "sobrenatural" por meio do imaginário popular.

Nos Aparados da Serra, encontramos as narrativas de aparições, de assombrações, de seres mágicos que povoam as grotas e as mentes de pessoas, principalmente, aquelas pessoas que viveram em um tempo distante da energia elétrica e das estradas automotivas. Essas histórias de uma literatura oral não são marcadas por um objeto ou personagem específico, mas se sobressaem de alguma forma como um elemento do imaginário popular, ressuscitadas pela narrativa oral de certos atores sociais, ou, como eles próprios dizem, pelo "causo acontecido". Casos que permeiam a literatura e a história oral.

Quando os aparelhos de televisão ainda faziam parte dos sonhos de poucos; quando somente os privilegiados desfrutavam das ondas do rádio e 0 cinema não passava de um evento dos dias festivos, encontrávamos os heróis e os vilões nas histórias contadas na calada da noite, à luz dos candeeiros e lamparinas. Curupira, Mboi-tatá, Gritador, Mula-sem-Cabeça, Boto, Bruxas e Amazonas eram, enfim, uma plêiade de muitos seres encantados que povoavam o lendário rústico brasileiro. Sejam de influência indígena, europeia ou africana, essas lendas e mitos sempre tiveram o seu papel de destaque quando proclamados no âmbito popular, seja enquanto fantasia, seja no âmago da realidade.

Para o fazer histórico, muitas vezes essas tradições não são levadas em consideração. Porém, partindo da ideia de que esses imaginários passam a constituir um sentimento de identidade para grupos, um sentimento de pertencimento com sistemas simbólicos que fazem sentido para o mundo "real" de algumas pessoas, é possível fazer história por meio dessas fontes, uma vez que encontra-se no "imaginário a inteligibilidade, a comunicação através da produção do discurso que efetua a reunião de representações coletivas numa linguagem" ${ }^{\prime 20}$, e que muitas vezes contém as experiências, os desejos, aspirações, motivações e sensações desses agentes sociais, além das relações de poderes entre os grupos, nesses sistemas simbólicos efetuados pela linguagem e comunicação.

Isso, ainda mais, se os "causos", forem verídicos. Se for uma experiência verdadeira, então o "causo" que aconteceu já é história! E se foi contado e recontado a um ou mais ouvinte. Então é arte, a arte de falar: é a literatura falada.

20 BACZKO, Bronislaw. A imaginação social. In: LEACH, Edmund et alii. Anthropos-homem. Lisboa, Imprensa Nacional/Casa da Moeda, 1985, p. 311. 


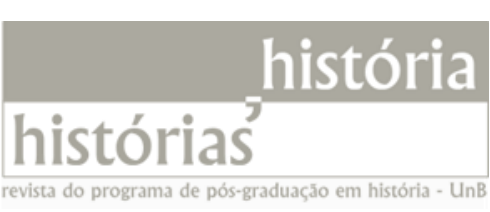

\section{Sobre 0 autor}

Frank Cardoso Lummertz é mestrando no Programa de Pós-Graduação em História da Universidade do Estado de Santa Catarina (UDESC), na linha de pesquisa Linguagens e Identificações, na área de História do Tempo Presente.

Artigo recebido em 15 de fevereiro de 2013. Aprovado em 20 de janeiro de 2014. 